\title{
Efficient ceramic anodes infiltrated with binary and ternary electrocatalysts for SOFCs operating at low temperatures
}

\author{
A. Mohammed Hussain*, Jens V.T. Høgh, Wei Zhang, Nikolaos Bonanos

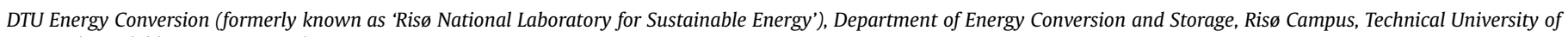 \\ Denmark, Roskilde 4000, Denmark
}

\section{H I G H L I G H T S}

- Infiltration of $\mathrm{Ni}, \mathrm{Pt}, \mathrm{Pd}, \mathrm{Ru}$ and CGO electrocatalysts precursors.

- Strontium titanate based ceramic anodes with an addition of $\mathrm{Ni}$ in noble metals containing electrocatalysts.

- Binary and ternary electrocatalyst for hydrogen oxidation.

- Low temperature solid oxide fuel cells.

\section{A R T I C L E I N F O}

\section{Article history:}

Received 21 January 2012

Received in revised form

6 May 2012

Accepted 16 May 2012

Available online 23 May 2012

\section{Keywords:}

Low temperature solid oxide fuel cell

anodes

Porous $\mathrm{Sr}_{0.94} \mathrm{Ti}_{0.9} \mathrm{Nb}_{0.1} \mathrm{O}_{3}$

Infiltration

Noble metals

$\mathrm{Ni}$ and CGO electrocatalyst

\begin{abstract}
A B S T R A C T
Electrocatalyst precursor of various combinations: $\mathrm{Pt}, \mathrm{Ru}, \mathrm{Pd}$, Ni and Gd-doped $\mathrm{CeO}_{2}$ (CGO) were infiltrated into a porous $\mathrm{Sr}_{0.94} \mathrm{Ti}_{0.9} \mathrm{Nb}_{0.1} \mathrm{O}_{3}$ (STN) backbone, to study the electrode performance of infiltrated ceramic anodes at low temperature ranges of $400-600^{\circ} \mathrm{C}$. The performance of the binary electrocatalyst infiltrated ceramic backbones are $\mathrm{Pt}-\mathrm{CGO}>\mathrm{Ru}-\mathrm{CGO}>\mathrm{Pd}-\mathrm{CGO}>\mathrm{Ni}-\mathrm{CGO}$. Ternary electrocatalyst of $\mathrm{Ni}$ $-\mathrm{Pd}-\mathrm{CGO}$ and $\mathrm{Ni}-\mathrm{Pt}-\mathrm{CGO}$ showed the lowest polarization resistance of 0.31 and $0.11 \Omega \mathrm{cm}^{2}$, respectively at $600{ }^{\circ} \mathrm{C}$ in $\mathrm{H}_{2} / 3 \% \mathrm{H}_{2} \mathrm{O}$. The average particle size of the ternary electrocatalyst was larger than the binary Pd-CGO and Pt-CGO due to the particle coarsening of Ni nanoparticles. High resolution transmission electron microscopic analysis on the best performing $\mathrm{Ni}-\mathrm{Pt}-\mathrm{CGO}$ electrocatalyst infiltrated anode reveals the formation of $\mathrm{Ni}-\mathrm{Pt}$ nanocrystalline alloy and a homogenous distribution of nanoparticles on STN backbone.
\end{abstract}

(c) 2012 Elsevier B.V. All rights reserved.

\section{Introduction}

Highly efficient electrodes and thin electrolytes are considered as major requirements for production of efficient power from low temperature SOFCs (LT-SOFCs) [1,2]. In particular to anodes, the most commonly studied for LT-SOFCs are based on cermet of nickel and an oxide ion conductor, e.g. Ni-CGO (Gd-doped ceria) [3]. Many recent studies on cermet anodes have been focused on controlling the parameters such as grain size, porosity, Ni and CGO ratio, stoichiometry of CGO etc., However, the polarization resistances remains relatively high at $400{ }^{\circ} \mathrm{C}$ in moisturized $\mathrm{H}_{2}$ fuel [3-5]. The poor redox stability of $\mathrm{Ni}$ and intolerance to

\footnotetext{
* Corresponding author. Tel.: +45 46775639; fax: +45 46775858.

E-mail addresses: abhu@risoe.dtu.dk, uzzain@gmail.com (A.M. Hussain).
}

hydrocarbon fuels indicates the need for the development of alternative anode materials for LT-SOFCs [6,7].

Perovskite type ceramic oxides have recently been considered as promising alternative anode materials for LT-SOFCs. $\mathrm{SrTiO}_{3}$ perovskite oxide has tolerance to sulfur and carbon poisoning and is considered as potential anodes for SOFCs operable in hydrocarbon fuels $[8,9]$. In particular, donor-doped $\mathrm{SrTiO}_{3}$ perovskite e.g., $\mathrm{Nb}$ doped $\mathrm{SrTiO}_{3}$ attracted the anode development researchers of SOFC [10]. This material exhibits metallic type electronic conductivity and good redox stability. Two known major drawbacks of using this material as SOFC anodes are poor electrocatalysts activity for $\mathrm{H}_{2}$ oxidation and low oxide ion conductivity. The incorporation of nanostructured electrocatalyst into an STN backbone (porous skeletal structure) makes it a potential candidate for LT-SOFC anodes. The electrocatalytic activity for hydrogen oxidation and oxide ion conductivity can be achieved by modifying the perovskite oxide with $\mathrm{CeO}_{2}$ or by infiltrations [11,12]. 
Nanostructured, oxide ion conducting materials based on $\mathrm{CeO}_{2}$ doped with other rare earth elements (Gd, Sm and Y) are widely recognized as mixed ionic and electronic conductors in reducing gas conditions. In addition, these materials have catalytic properties for hydrogen oxidation [13]. A few percent (1-2 wt. \%) of metallic catalyst such as $\mathrm{Ni}$ mixed with Gd-doped ceria (CGO) infiltrated in $\mathrm{Sr}_{0.94} \mathrm{Ti}_{0.9} \mathrm{Nb}_{0.1} \mathrm{O}_{3}$ (STN) backbone enhanced the SOFC anode performance considerably compared to CGO alone [12,14]. A careful control on loading of electrocatalyst in STN helps in tuning the performance. Results reported in literature prompts to explore other catalytic metals for hydrogen oxidation in combination with $\mathrm{Ni}$ [15-17]. Infiltration technology significantly contributes to reducing the quantity of noble metals needed to obtain beneficial electrochemical properties and allows the exploration of nanostructured, noble metal-ceramic catalysts in combinations [17]. Although Ni-CGO infiltrated STN has shown reasonably good anode performance, further improvements for LT-SOFC anodes can be made by employing a small quantity of noble metals e.g. Pt, Ru, Pd etc., in combination with $\mathrm{Ni}$.

This work concentrates on electrochemical characterization of STN anodes infiltrated with binary electrocatalysts Pt-CGO, $\mathrm{Ru}-\mathrm{CGO}$, Pd-CGO, and Ni-CGO operating at low temperature $\left(<600^{\circ} \mathrm{C}\right)$. $\mathrm{Pt}-\mathrm{CGO}$ showed the best performance in comparison to all other binary electrocatalyst. Among the ternary electrocatalysts being investigated, $\mathrm{Ni}-\mathrm{Pt}-\mathrm{CGO}$ infiltrated STN anodes showed an excellent performance. Emphasis was given to understand the nanocrystalline properties of $\mathrm{Ni}-\mathrm{Pt}$ in the $\mathrm{Ni}-\mathrm{Pt}-\mathrm{CGO}$ using highresolution transmission electron microscopy. It is observed that the lattice parameter of $\mathrm{Ni}-\mathrm{Pt}$ alloy is located in between the two individual metals (i.e., $\mathrm{Ni}$ and $\mathrm{Pt}$ ). The observed alloying of the metallic catalyst and nanostructured morphology of the electrocatalyst are believed to be the reason for an improved anode performance.

\section{Experimental section}

\subsection{STN synthesis}

STN perovskite oxide was prepared using a wet chemical synthesis route. Strontium carbonate $\left(\mathrm{SrCO}_{3}\right)$, titanium (IV) isopropoxide $\left(\mathrm{Ti}\left\{\mathrm{OCH}\left(\mathrm{CH}_{3}\right)_{2}\right\}_{4}\right)$ and niobium oxalate $\left(\mathrm{C}_{2} \mathrm{NbO}_{4}\right)$ were used as starting materials (Sigma Aldrich) to obtain an STN composition of $\mathrm{Sr}_{0.94} \mathrm{Ti}_{0.9} \mathrm{Nb}_{0.1} \mathrm{O}_{3}$. A $260 \mathrm{ml}$ of titanium (IV) isopropoxide and $160 \mathrm{ml}$ of niobium oxalate was mixed separately in an already prepared $500 \mathrm{ml}$ ethanol and water mixture in a proportion of $1: 1.5$. The resulted precipitates were filtered, washed in ethanol and dried. Subsequently, the hydroxides were dissolved separately in citric acid monohydrate $\left(\mathrm{HOC}(\mathrm{COOH})\left(\mathrm{CH}_{2}\right.\right.$ $\mathrm{COOH})_{2} \cdot \mathrm{H}_{2} \mathrm{O}$ ) with the addition of $20 \mathrm{ml}$ hydrogen peroxide $\left(\mathrm{H}_{2} \mathrm{O}_{2}\right)$ solution. The concentration of $\mathrm{Nb}$ and $\mathrm{Ti}$ containing solutions was 5.7 and $2.1 \mathrm{wt}$ \%. About $13.9 \mathrm{~g}$ of $\mathrm{SrCO}_{3}$ powder along with $20 \mathrm{ml}$ of $\mathrm{H}_{2} \mathrm{O}_{2}$ was added slowly into $125.5 \mathrm{~g}$ of $\mathrm{Ti}$ and $63 \mathrm{~g}$ of $\mathrm{Nb}$ ion containing solutions. This mixture was placed in a crucible and heated on a hot plate at $300{ }^{\circ} \mathrm{C}$ for $5 \mathrm{~h}$. The resulting solids were heat-treated at $1000{ }^{\circ} \mathrm{C}$ for $3 \mathrm{~h}$ and ground to fine powder. The crystalline peaks of STN were confirmed using XRD for each batch.

\subsection{Symmetrical cell preparation for the characterization of anode}

STN powder was formulated as a screen printing ink following an in-house preparation procedure using surfactant, plasticizer and a binder and mixed thoroughly by using a mechanical shaker overnight. The screen printed STN on a dense ScYSZ (10 mol \% $\mathrm{Sc}_{2} \mathrm{O}_{3}, 1 \mathrm{~mol} \% \mathrm{Y}_{2} \mathrm{O}_{3}$ stabilized $\mathrm{ZrO}_{2}$ ) tapes of $120 \mu \mathrm{m}$ thick were sintered for $4 \mathrm{~h}$ in a reducing atmosphere $\left(9 \% \mathrm{H}_{2} / \mathrm{N}_{2}\right)$. The porous
STN anodes were deposited on both sides of the ScYSZ electrolyte with an area of $6 \times 6 \mathrm{~cm}^{2}$. The tape was cut into smaller pieces measuring an area of $0.25 \mathrm{~cm}^{2}$ for use in the electrochemical setup.

A $0.75 \mathrm{M}$ of $\mathrm{CGO}$ precursor solution was prepared by dissolving cerium nitrate $\left(\mathrm{Ce}\left(\mathrm{NO}_{3}\right)_{3} \cdot 6 \mathrm{H}_{2} \mathrm{O}\right)$ and gadolinium nitrate $\left(\mathrm{Gd}\left(\mathrm{NO}_{3}\right)_{3} \cdot 6 \mathrm{H}_{2} \mathrm{O}\right)$ in $\mathrm{H}_{2} \mathrm{O}$ along with polymer surfactants. The composition of the precursor was $\mathrm{Ce}_{0.8} \mathrm{Gd}_{0.2} \mathrm{O}_{2-\delta}$. The precursor solution of $\mathrm{Ni}-\mathrm{CGO}, \mathrm{Pt}-\mathrm{CGO}$ contains $25 \mathrm{wt}$. \% of $\mathrm{Ni}$ and $25 \mathrm{wt}$. \% of $\mathrm{Pt}$, respectively relative to $\mathrm{CGO}$ and was prepared by dissolving $0.6 \mathrm{M}$ nickel nitrate $\left(\mathrm{Ni}\left(\mathrm{NO}_{3}\right)_{2} \cdot 6 \mathrm{H}_{2} \mathrm{O}\right)$ and $0.2 \mathrm{M}$ of tetra ammine platinum (II) nitrate $\left(\mathrm{H}_{12} \mathrm{~N}_{6} \mathrm{O}_{6} \mathrm{Pt}\right)$ in already prepared $\mathrm{CGO}$ precursors.

For Pd-CGO, approximately $10 \mathrm{wt}$ \% Pd in the form of palladium nitrate $\left(\mathrm{Pd}\left(\mathrm{NO}_{3}\right)_{2} \cdot 6 \mathrm{H}_{2} \mathrm{O}\right)$ with a concentration of $0.6 \mathrm{M}$ was dissolved in $\mathrm{CGO}$ precursors. In case of the $\mathrm{Ru}-\mathrm{CGO}$ containing infiltrates, $25 \mathrm{wt}$ \% of $\mathrm{Ru}$ in the form of ruthenium chloride $\left(\mathrm{RuCl}_{3}\right.$. $\mathrm{xH}_{2} \mathrm{O}$ ) with a concentration of $0.3 \mathrm{M}$ was dissolved in CGO precursor. The infiltrated STN anodes were prepared by adding a few drops of the precursor into the symmetrical cells, after which they were placed in a vacuum chamber. Vacuum was applied in order to remove air bubbles from the porous STN backbone and to facilitate the liquid precursor to homogeneously coat the surface of the anode. For binary electrocatalyst (BEC) infiltration, Pt-CGO, $\mathrm{Ru}-\mathrm{CGO}, \mathrm{Pd}-\mathrm{CGO}$ and $\mathrm{Ni}-\mathrm{CGO}$ were infiltrated 3 times to increase the loadings in porous STN; after each infiltration the cells were calcined at $350{ }^{\circ} \mathrm{C}$ for $1 \mathrm{~h}$. In case of ternary electrocatalyst (TEC) infiltration such as $\mathrm{Ni}-\mathrm{Pd}-\mathrm{CGO}$ and $\mathrm{Ni}-\mathrm{Pt}-\mathrm{CGO}$, dual infiltrations were carried out. Firstly, Pd-CGO and Pt-CGO were infiltrated two times and followed by infiltration of Ni-CGO 3 times. The heat treatments were performed after each infiltration. The change in weight after calcinations was recorded after each infiltration. The EC samples for physico chemical and microscopic analysis were prepared under the similar conditions as that of electrocatalysts infiltrated in STN backbone.

\subsection{Anode characterization}

A Solartron SI1260 frequency response analyzer was used to measure the impedance of the symmetrical cells. The symmetrical cells were electrically contacted using Pt-paste (Ferro GmbH) and a Pt-grid. The polarization resistance of Pt paste as anode is very high $\left(123 \Omega \mathrm{cm}^{2}\right.$ at $650{ }^{\circ} \mathrm{C}$ in $\mathrm{H}_{2} / 3 \% \mathrm{H}_{2} \mathrm{O}$ ) owing to their larger grain sizes and lack of oxide ion conductivity. The contribution from Pt current collector is negligible and the same current collector was used for all the anodes to compare the results $[5,18]$. The cells were heated to $650{ }^{\circ} \mathrm{C}$ in $9 \% \mathrm{H}_{2} / \mathrm{N}_{2}$, where after the gas was changed to dry $\mathrm{H}_{2}\left(\mathrm{EMF}=-1.312 \mathrm{~V}\right.$ vs. air $\left.@ 650{ }^{\circ} \mathrm{C}\right)$ and kept for $12 \mathrm{~h}$. The impedance spectra were recorded by applying an amplitude of $50 \mathrm{mV}$ (the output voltage of the Solartron varies from 5 to $50 \mathrm{mV}$ depending on the temperature of measurement and the resulting cell impedance) in the frequency range of $1 \mathrm{MHz}-1 \mathrm{mHz}$. The impedance was measured in the temperature range 650 to $350{ }^{\circ} \mathrm{C}$. The partial pressure of oxygen, $\left(\mathrm{pO}_{2}\right)$ was measured using an oxygen sensor. The EMF values were $-1.125,-1.131,-1.140$ and $-1.147 \mathrm{~V}$ vs. air and the corresponding $\mathrm{pO}_{2}$ were $10^{-26}, 10^{-27}$, $10^{-29}$, and $10^{-31} \mathrm{~atm}$ at $650,600,550$ and $500{ }^{\circ} \mathrm{C}$, respectively. These values correspond very well with the intended gas composition of $3 \% \mathrm{H}_{2} \mathrm{O} / \mathrm{H}_{2}$. All the obtained impedance spectra were corrected for inductance in the range of $30-60 \mathrm{nH}$ originating from the leads of electrochemical setup depending on the sample position. The impedance spectra were fitted with equivalent circuit model using the code ZSimpWin with complex non-linear least squares fitting (CNLS). During impedance measurements on symmetrical cells, one side of the electrode will function as anode, while the other side functions as cathode. The anode and cathode 
side changes with the alternating current. Hence, the reactions under investigation when using symmetrical cells are the hydrogen oxidation and the reduction of steam as shown in reactions (1) and (2).

$$
\begin{aligned}
& \mathrm{H}_{2}(\mathrm{~g})+\mathrm{O}^{2-} \rightarrow \mathrm{H}_{2} \mathrm{O}(\mathrm{g})+2 \mathrm{e}^{-} \text {(anodic current) } \\
& \mathrm{H}_{2} \mathrm{O}(\mathrm{g})+2 \mathrm{e}^{-} \rightarrow \mathrm{H}_{2}(\mathrm{~g})+\mathrm{O}^{2-} \text { (cathodic current) }
\end{aligned}
$$

The crystal structure of the sintered STN anodes on ScYSZ symmetrical cells were determined using XRD with a Bruker D8 Bragg-Brentano diffractometer with $\mathrm{Cu} \mathrm{K} \alpha$ radiation and compared with as-sintered STN powders. The microstructures of the symmetric cells and the STN backbone were examined by scanning electron microscope (SEM). A JEM-3000F transmission electron microscope was used to characterize the microstructure and chemical compositions of the samples.

\section{Results and discussions}

Fig. 1 shows the XRD of the TECs, Ni-Pd-CGO and Ni-Pt-CGO and are compared to that of $\mathrm{Ni}-\mathrm{CGO}$ and CGO. The formation of fluorite-like single phase of CGO is evident even at a low calcination temperature of $350{ }^{\circ} \mathrm{C}(1 \mathrm{~h}$, in air). No reaction occurred between the metal and ceramic phase, in other words, metal exists as a separate dispersed phase in a CGO matrix. XRD pattern of both TECs showed (111) reflex of Ni; however Pt and Pd peaks are not identified. The poor detection of X-ray reflections of such catalysts was already reported and is ascribed to its highly dispersed nature [19]. Moreover, a shift toward lower angle in $\mathrm{Ni}$ (111) is observed in $\mathrm{Ni}-\mathrm{Pt}-\mathrm{CGO}$ indicating a possible alloying.

The low thermal treatment of electrocatalysts at $650{ }^{\circ} \mathrm{C}$ in reducing atmosphere resulted in the nanostructured crystalline phase. The high resolution-transmission electron microscopy (HRTEM) analysis was performed for the best performing $\mathrm{Ni}-\mathrm{Pt}-\mathrm{CGO}$ and is shown in Fig. 2. Both CGO and metallic phases were identified. The perpendicular (111) and (2-20) crystal planes of CGO are located at the right side of the figure; two small metallic grains are located on the left. The EDX quantification (Fig. S1 in the supporting information) reveals the average weight percent of $\mathrm{Ni} / \mathrm{Pt}$ is in the ratio of 95:100 from 15 regions, consistent with the nominal ratio. Furthermore, a close observation on Fig. 2 illustrates that the lattice parameter of the alloy phase is situated in between those of $\mathrm{Ni}$ and $\mathrm{Pt}$, indicating the formation of $\mathrm{Ni}-\mathrm{Pt}$ alloy phase besides the CGO phase. However a small variation in lattice parameter at different area of measurements is envisaged, which are ascribed to coexistence of Ni and Pt elements in the Pt-Ni alloy phase. The Pt-Ni alloy

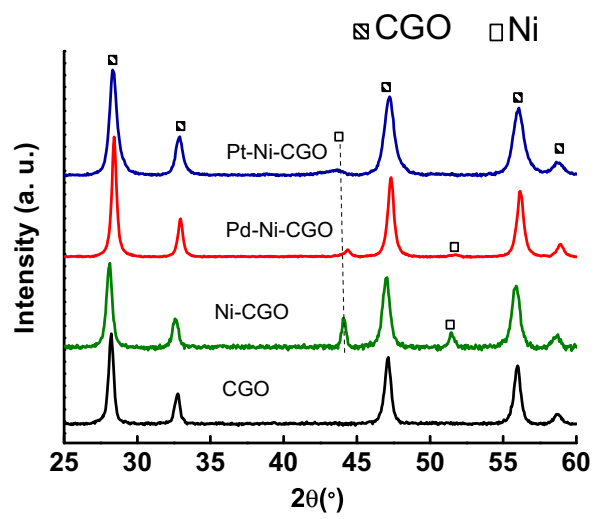

Fig. 1. XRD patterns of $\mathrm{CGO}, \mathrm{Ni}-\mathrm{CGO}, \mathrm{Pd}-\mathrm{Ni}-\mathrm{CGO}$ and $\mathrm{Pt}-\mathrm{Ni}-\mathrm{CGO}$ electrocatalysts. The fluorite phase of CGO and $\mathrm{Ni}$ were labeled by a dashed line.

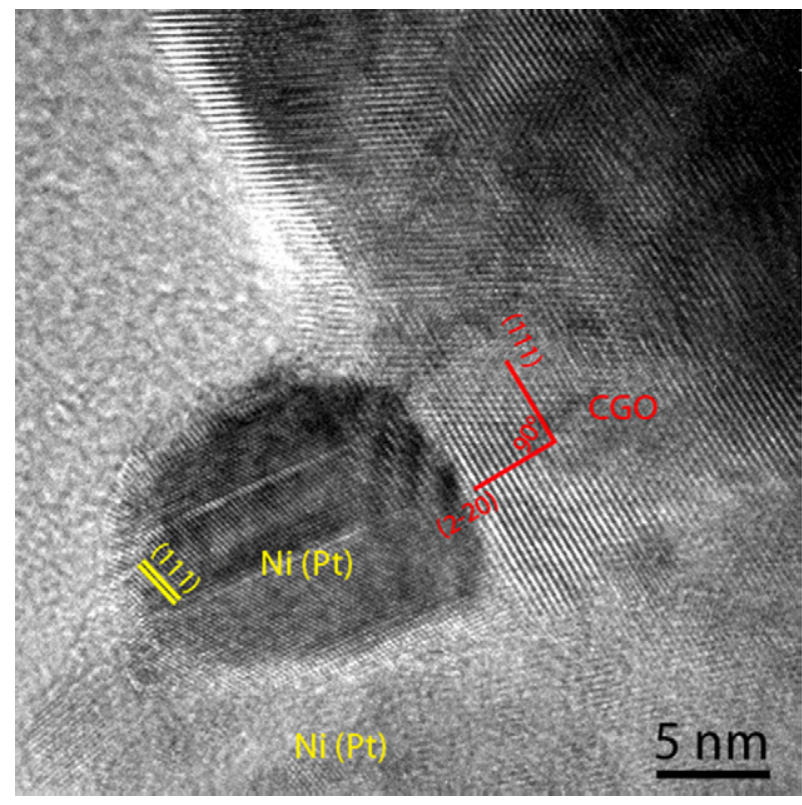

Fig. 2. HR-TEM image of $\mathrm{Pt}-\mathrm{Ni}-\mathrm{CGO}$ electrocatalyst. Heat treated at $650{ }^{\circ} \mathrm{C}$ in reducing atmosphere for $12 \mathrm{~h}$.

phase adopts the same face-centered-cubic (FCC) structure as Pt and Ni phase, which are in good agreement with the XRD data. Additionally, in contrast to the pure Ni phase, some resultant lattice expansion was observed, e.g., the inter planar spacing of (111) plane is $2.3 \%$ larger than that of $\mathrm{Ni}$. The resulted particle size of the infiltrated electrocatalysts were found to be around 5-10 nm and are highly dispersed.

The backbone for infiltration used in this study is $\mathrm{Nb}$-doped, $\mathrm{Sr}$ deficient $\mathrm{SrTiO}_{3}$ cubic perovskite with a composition of $\mathrm{Sr}_{0.94} \mathrm{Ti}_{0.9} \mathrm{Nb}_{0.1} \mathrm{O}_{3}$ prepared using a wet chemical method (see the Experimental Section for details). The powder XRD pattern of STN with a heat treatment at $1000{ }^{\circ} \mathrm{C}$ for $4 \mathrm{~h}$ (Fig. S2a in the supporting information) shows a single perovskite phase without formation of any secondary phases. The anodes were characterized using a symmetrical cell configuration of STN-ScYSZ-STN (XRD pattern of this symmetrical cell is shown in Fig. S2b of supporting information). The XRD pattern resembles as that of STN powder and few minor secondary phases were also detected. Formation of reduced $\mathrm{TiO}_{2}$ (rutile) is expected for an STN sintered in reducing atmosphere $[10,20]$. However, the intensity of those unidentified peaks was very small. ScYSZ electrolyte peaks were seen along with STN peaks. The signal from the electrolyte was presumably detected through the porous electrode or could be from the sides of the symmetrical cell, where the electrolyte was exposed.

The scanning electron microscopy (SEM) micrographs of the BEC and TEC infiltrated STN anodes are shown in Fig. 3. The micrograph of BECs and TECs infiltrated STN anodes shows a uniform distribution of nanostructured CGO. It has also formed a percolated network in the STN backbone, which facilitates oxide ion conduction throughout the backbone. The nano-sized metal phase is found well dispersed in the CGO matrix and they are expected to act as active sites for hydrogen oxidation. For the Ni-Pd-CGO and $\mathrm{Pt}-\mathrm{Pd}-\mathrm{CGO}$, the particle size of the metal phase is larger than $\mathrm{Pd}-\mathrm{CGO}$ and $\mathrm{Pt}-\mathrm{CGO}$, respectively and is attributed to rapid particle growth of Ni nanoparticles than Pt and Pd nanoparticles.

Fig. 4a shows the impedance measurements of STN symmetrical cells infiltrated with $\mathrm{Ni}-\mathrm{CGO}, \mathrm{Pd}-\mathrm{CGO}, \mathrm{Ru}-\mathrm{CGO}$ and $\mathrm{Pt}-\mathrm{CGO}$ electroctalysts in $\mathrm{H}_{2} / 3 \% \mathrm{H}_{2} \mathrm{O}$ at $600{ }^{\circ} \mathrm{C}$. The obtained impedance spectra at $600{ }^{\circ} \mathrm{C}$ were fitted using the equivalent circuits, $\left({ }^{1} R_{0}\right)$ 


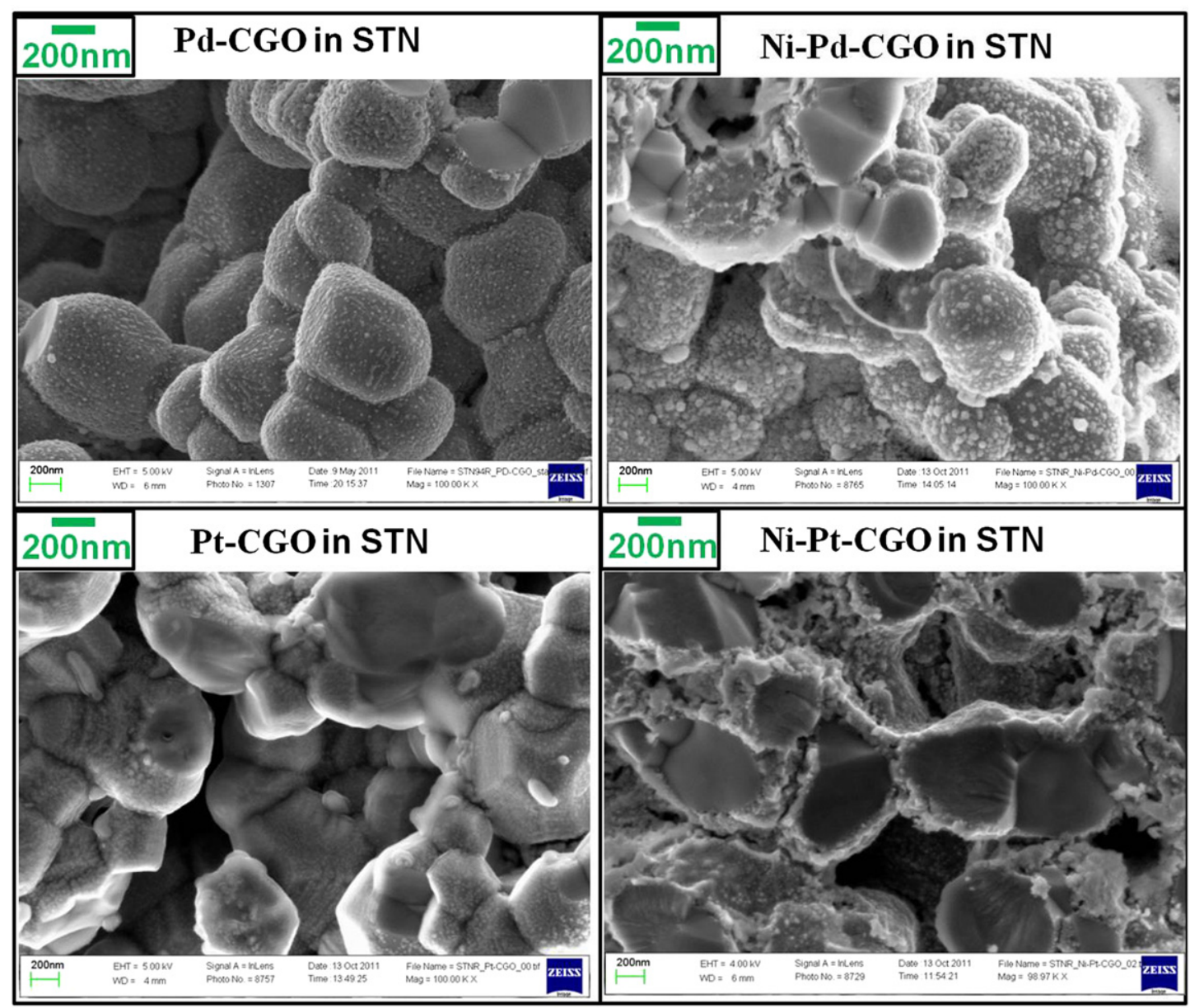

Fig. 3. SEM images (fractured cross section) of post-tested $\mathrm{Pd}-\mathrm{CGO}, \mathrm{Ni}-\mathrm{Pd}-\mathrm{CGO}, \mathrm{Pt}-\mathrm{CGO}$ and $\mathrm{Ni}-\mathrm{Pt}-\mathrm{CGO}$ infiltrated STN anodes.

$\left(R_{1} Q_{1}\right),\left(R_{2} Q_{2}\right)$ and $\left({ }^{1} R_{0}\right)\left(R_{0} Q_{0}\right)\left(R_{1} Q_{1}\right)\left(R_{2} Q_{2}\right)$ with the number of sub-circuits depending on the number of impedance arcs obtained. The sum of ${ }^{1} R_{0}$ and $R_{0}$ corresponds to the ohmic resistance of the electrolyte. $R_{1}$ and $R_{2}$ is the resistance due to the electrode processes. $Q_{1}$ and $Q_{2}$ correspond to the constant phase elements. $R_{0}$ was in the range of $1.5-1.9 \Omega \mathrm{cm}^{2}$ at $600{ }^{\circ} \mathrm{C}$ for all the infiltrated anodes. The reason for this variation in ohmic resistance is discussed in the last section of this paper. The $R_{\mathrm{p}}$ (i.e. summation of $R_{1}$ and $R_{2}$ ) of the STN anode without infiltration shows a high value of $352 \Omega \mathrm{cm}^{2}$; however it reduces to $0.96,0.57,0.51$ and $0.16 \Omega \mathrm{cm}^{2}$ for $\mathrm{Ni}-\mathrm{CGO}, \mathrm{Pd}-\mathrm{CGO}, \mathrm{Ru}-\mathrm{CGO}$ and $\mathrm{Pt}-\mathrm{CGO}$, respectively at $600{ }^{\circ} \mathrm{C}$. The drastic improvements in the electrode performance are due to the catalytic activity of the infiltrated $\mathrm{Ni}, \mathrm{Pd}, \mathrm{Ru}, \mathrm{Pt}$ catalyst and CGO $[16,21,22]$. Although CGO exhibits catalytic activity, it cannot be used as a standalone electrocatalyst as such owing to its limited catalytic activity. The volume fractions of electrocatalyst infiltrated in the STN backbone were determined by measuring the change in weight after calcinations and is listed in Table 1.

Fig. 4b shows the Arrhenius plot of $R_{\mathrm{p}}$. STN without infiltration has the highest slope in the Arrhenious plot. The activation energy $\left(E_{\mathrm{a}}\right)$ of STN is $1.14 \mathrm{eV}$. The slopes are slightly reduced with various infiltrates in STN backbone. The $E_{\mathrm{a}}$ of $\mathrm{Ni}-\mathrm{CGO}, \mathrm{Pt}-\mathrm{CGO}, \mathrm{Ru}-\mathrm{CGO}$ and Pd-CGO in STN anodes were 1.09, 0.84, 0.93, and $0.97 \mathrm{eV}$, respectively. The values of $E_{\mathrm{a}}$ are almost the same for all the infiltrated STN anodes despite the lowering of $R_{\mathrm{p}}$.

The electrochemical performances of $\mathrm{Ni}-\mathrm{CGO}$ with addition of noble metal catalysts, such as Pd and Pt have been investigated using EIS. Fig. 5a shows the impedance spectra of STN infiltrated with
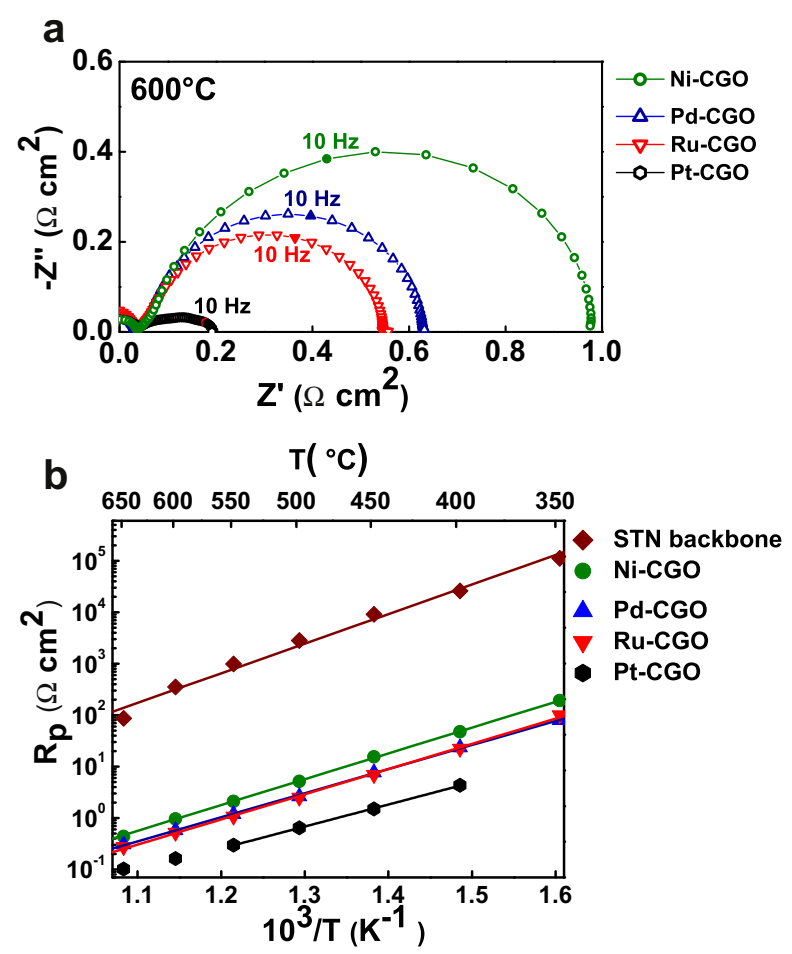

Fig. 4. a) Impedance spectra of $\mathrm{Ni}-\mathrm{CGO}, \mathrm{Pd}-\mathrm{CGO}, \mathrm{Ru}-\mathrm{CGO}$ and $\mathrm{Pt}-\mathrm{CGO}$ in $3 \% \mathrm{H}_{2} \mathrm{O} / \mathrm{H}_{2}$ at $600{ }^{\circ} \mathrm{C}$ and b) Arrhenius plot of electrode polarization resistance, $R_{\mathrm{p}}$. 
Table 1

Loading of electrocatalysts and the resulted polarization resistance $\left(R_{\mathrm{p}}\right)$ at 500 and $600{ }^{\circ} \mathrm{C}$. The calculated activation energies of the anodes are listed.

\begin{tabular}{lclll}
\hline Electrocatalysts & $\begin{array}{l}\text { Loading } \\
(\text { Vol. \%) }\end{array}$ & $\begin{array}{l}R_{\mathrm{P}}\left(\Omega \mathrm{cm}^{2}\right) \\
\text { at } 600{ }^{\circ} \mathrm{C}\end{array}$ & $\begin{array}{l}R_{\mathrm{P}}\left(\Omega \mathrm{cm}^{2}\right) \\
\text { at } 500{ }^{\circ} \mathrm{C}\end{array}$ & $\begin{array}{l}\text { Activation } \\
\text { energy }(\mathrm{eV})\end{array}$ \\
\hline $\mathrm{Ni}^{1}-\mathrm{CGO}$ & 12.66 & 0.96 & 5.13 & 1.09 \\
$\mathrm{Pt}^{1}-\mathrm{CGO}$ & 7.63 & 0.16 & 0.64 & 0.84 \\
$\mathrm{Pd}^{1}-\mathrm{CGO}$ & 11.86 & 0.57 & 2.62 & 0.93 \\
$\mathrm{Ru}^{1}-\mathrm{CGO}$ & 18.09 & 0.51 & 2.5 & 0.97 \\
$\mathrm{Ni}$ containing mixed catalysts & & & \\
$\mathrm{Ni}^{1}-\mathrm{Pt}^{2}-\mathrm{CGO}$ & 13.20 & 0.1 & 0.3 & 0.85 \\
$\mathrm{Ni}^{1}-\mathrm{Pd}^{2}-\mathrm{CGO}$ & 14.26 & 0.31 & 1.62 & 0.98 \\
\hline
\end{tabular}

$\mathrm{Ni}-\mathrm{Pd}-\mathrm{CGO}$ and are compared with Pd-CGO. The values of $R_{\mathrm{p}}$ determined from impedance spectra of $\mathrm{Ni}-\mathrm{Pd}-\mathrm{CGO}$ infiltrated anodes is $0.31 \Omega \mathrm{cm}^{2}$, while that of Pd-CGO is $0.57 \Omega \mathrm{cm}^{2}$ at $600{ }^{\circ} \mathrm{C}$. The parameters concerning the electrochemical characterization from the impedance spectra of Fig. 5a are listed Table 2. The value of $R_{\mathrm{p}}$ of Pd-CGO infiltrated anodes showed a single arc with a characteristics frequency of $(13 \mathrm{~Hz})$. Moreover, in this spectrum overlapping of electrode processes is observed and is difficult to interpret its physical meaning.

In the case of Ni-Pd-CGO infiltrated anodes, the impedance spectrum showed three distinct electrode processes, $\left(R_{1} Q_{1}\right),\left(R_{2} Q_{2}\right)$ and $\left(R_{3} Q_{3}\right)$ at high frequency $(1 \mathrm{MHz}-1000 \mathrm{~Hz})$, middle frequency $(1000-10 \mathrm{~Hz})$ and low frequency $(10-0.01 \mathrm{~Hz})$, respectively. The $R_{1}$ at high frequency (HF) corresponds to interfacial resistance between the electrode/electrolyte [23], $R_{2}$ is resistance associated electrochemical hydrogen oxidation reaction at middle frequencies (MF) [16] and $R_{3}$ is due to the gas diffusion resistance at low frequency

\section{a}
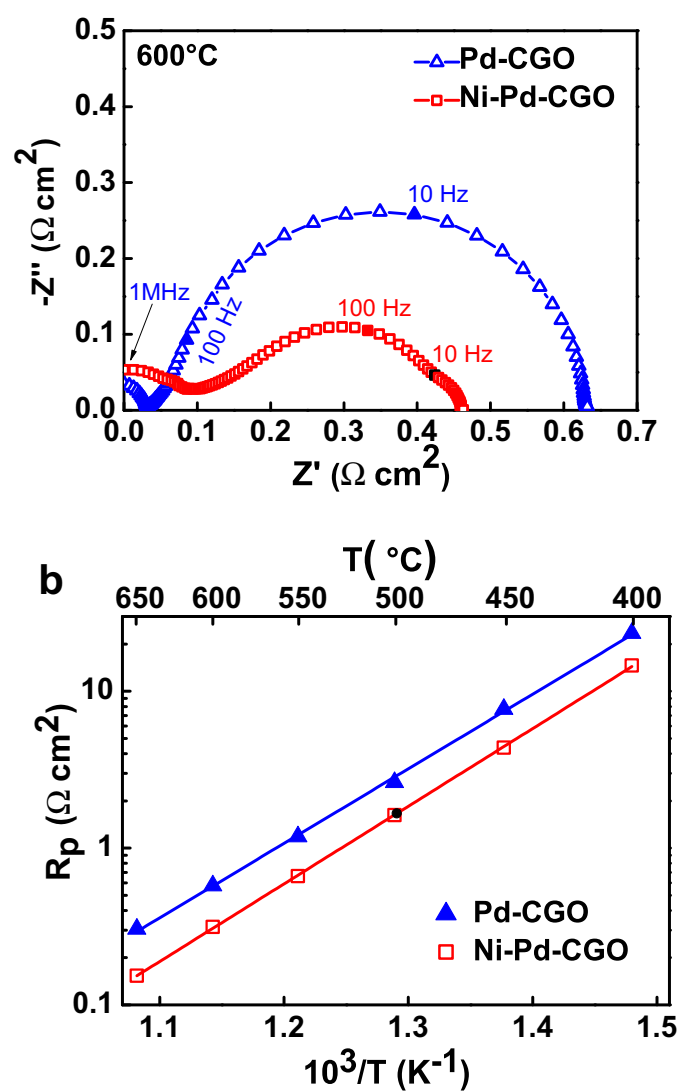

Fig. 5. a) Impedance spectra of $\mathrm{Pd}-\mathrm{CGO}$ and $\mathrm{Ni}-\mathrm{Pd}-\mathrm{CGO}$ in $3 \% \mathrm{H}_{2} \mathrm{O} / \mathrm{H}_{2}$ at $600{ }^{\circ} \mathrm{C}$ and b) Arrhenius plot of electrode polarization resistance, $R_{\mathrm{p}}$.
Table 2

Resistances $R_{1}, R_{2}$ and $R_{3}$ and summit frequencies obtained from the equivalent circuit analysis of the impedance spectra at $600{ }^{\circ} \mathrm{C}$ in $\mathrm{H}_{2} / \mathrm{H}_{2} \mathrm{O}$.

\begin{tabular}{|c|c|c|c|c|c|c|c|}
\hline \multirow[t]{2}{*}{ Electrocatalysts } & \multicolumn{2}{|l|}{$\left(R_{1} Q_{1}\right)_{\mathrm{HF}}$} & \multicolumn{2}{|l|}{$\left(R_{2} Q_{2}\right)_{\mathrm{MF}}$} & \multicolumn{2}{|l|}{$\left(R_{3} Q_{3}\right)_{\mathrm{LF}}$} & \multirow{2}{*}{$\begin{array}{l}R_{\mathrm{p}} \\
\left(\Omega \mathrm{cm}^{2}\right)\end{array}$} \\
\hline & $\begin{array}{l}R_{1} \\
\left(\Omega \mathrm{cm}^{2}\right)\end{array}$ & $\begin{array}{l}F_{\max } \\
\mathrm{HF}(\mathrm{Hz})\end{array}$ & $\begin{array}{l}R_{2} \\
\left(\Omega \mathrm{cm}^{2}\right)\end{array}$ & $\begin{array}{l}F_{\max } \\
\mathrm{HF}(\mathrm{Hz})\end{array}$ & $\begin{array}{l}R_{3} \\
\left(\Omega \mathrm{cm}^{2}\right)\end{array}$ & $\begin{array}{l}F_{\max } \\
\mathrm{HF}(\mathrm{Hz})\end{array}$ & \\
\hline $\mathrm{Pd}-\mathrm{CGO}$ & - & - & - & - & 0.6 & 13 & 0.6 \\
\hline $\mathrm{Ni}-\mathrm{Pd}-\mathrm{CGO}$ & 0.2 & 1940 & 0.2 & 144 & 0.015 & 9 & 0.41 \\
\hline $\mathrm{Pt}-\mathrm{CGO}$ & 0.09 & 2000 & 0.05 & 133 & 0.02 & 15 & 0.16 \\
\hline $\mathrm{Ni}-\mathrm{Pt}-\mathrm{CGO}$ & 0.07 & 830 & - & - & 0.03 & 10 & 0.1 \\
\hline
\end{tabular}

(LF). A small arc $\left(R_{0} Q_{0}\right)$ originating at very high frequency of $1 \mathrm{MHz}$ for the impedance spectra is associated with the bulk properties of the electrolyte and is confirmed by observing the impedance spectra measured at low temperatures. For each electrode process, the characteristic frequencies are listed in Table 2 . The improvement in electrode performance can be ascribed to the synergistic electrocatalytic activty of Pd and Ni catalyst as reported in literature [16]. The activation energies of this electrocatalyst infiltrated anodes are calculated from the Arrhenius plot shown in Fig. 5b. $E_{\mathrm{a}}$ of $\mathrm{Ni}-\mathrm{Pd}-\mathrm{CGO}$ is $0.98 \mathrm{eV}$ and this value is similar to Pd-CGO.

Similarly, the parameters concerning the electrochemical characterization of the $\mathrm{Ni}-\mathrm{Pt}-\mathrm{CGO}$ infiltrated anodes are listed in Table 2. The value of $R_{\mathrm{p}}$ of $\mathrm{Ni}-\mathrm{Pt}-\mathrm{CGO}$ electrocatalyst infiltrated anode is $0.1 \Omega \mathrm{cm}^{2}$ determined from Fig. 6a. The value of $R_{\mathrm{p}}$ is lowest of the tested anodes and lower than Pt-CGO infiltrated anode, which is $0.16 \Omega \mathrm{cm}^{2}$. For Pt-CGO infiltrated anodes $R_{1}, R_{2}$ and $R_{3}$ resistances associated with electrode processes described earlier were observed. The electrode resistance at HF associated with electrode electrolyte contact is lowered with $\mathrm{Ni}-\mathrm{Pt}-\mathrm{CGO}$ and MF arc associated with electrochemical hydrogen oxidation reaction resistance $R_{1}$ is completely disappeared. However, $R_{3}$ associated with gas diffusion at LF increased slightly. Most of the beneficial
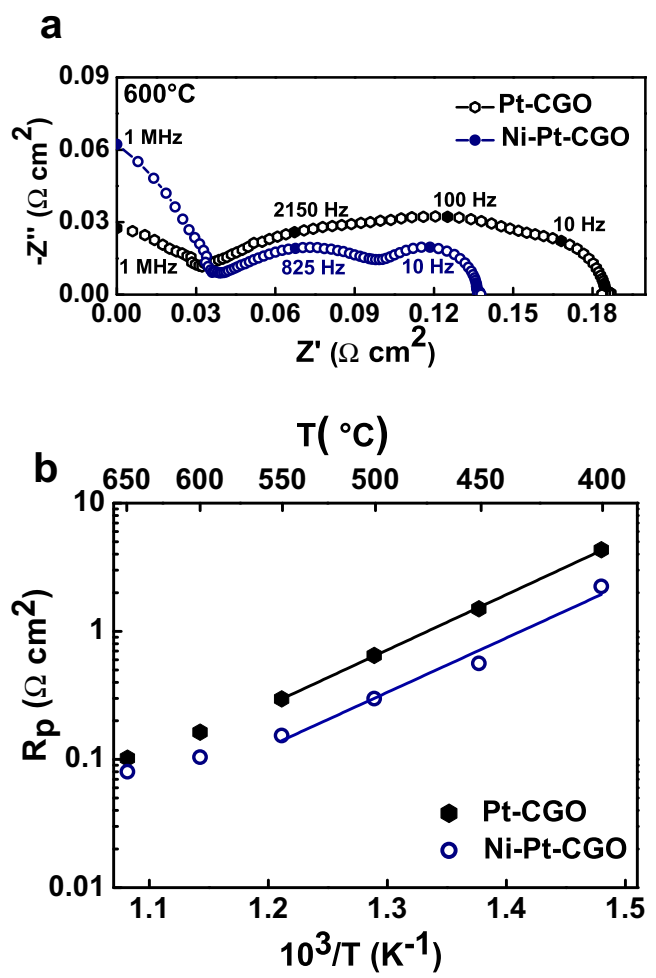

Fig. 6. a) Impedance spectra of $\mathrm{Pt}-\mathrm{CGO}$ and $\mathrm{Ni}-\mathrm{Pt}-\mathrm{CGO}$ in $3 \% \mathrm{H}_{2} \mathrm{O} / \mathrm{H}_{2}$ at $600{ }^{\circ} \mathrm{C}$ and b) Arrhenius plot of electrode polarization resistance, $R_{\mathrm{p}}$. 
electrochemical properties are achieved from the Pt catalyst and nanocrystalline morphology of TEC. $E_{\mathrm{a}}$ of $\mathrm{Ni}-\mathrm{Pt}-\mathrm{CGO}$ anode is $0.85 \mathrm{eV}$ as determined from the Arrhenius plot shown in Fig. 6b. $E_{\mathrm{a}}$ of Pt containing ternary and binary electrocatalyst are almost in the same range and has lower activation energy compared to other catalysts.

The same $R_{0}$ is expected among the anodes at one particular temperature e.g. $600{ }^{\circ} \mathrm{C}$. This is a good indication in estimation of correct electrode polarization resistance (Fig. S3 in the supporting information shows the temperature dependence of $R_{0}$ ). The solid line indicates the $R_{0}$ of ScYSZ electrolyte for a thickness of $120 \mu \mathrm{m}$ and was calculated based on the ionic conductivity reported in literature [24]. $E_{\mathrm{a}}$ obtained for ScYSZ electrolyte is $1.3 \mathrm{eV}$. The $R_{0}$ of the anodes infiltrated with various electrocatalyst are almost the same and have the same slope as that of theoretically calculated ScYSZ. However, the small variations in $R_{0}$ at high temperatures are probably due to the micro structural variations of the backbone and current collector contacts.

\section{Conclusions}

Nanostructured electrocatalyst suitable for low temperature solid oxide fuel cells anode were evaluated. Pt-CGO infiltrated STN anodes showed an electrode polarization resistance of $0.16 \Omega \mathrm{cm}^{2}$, which is the lowest among the binary electrocatalysts. The addition of $\mathrm{Ni}$ in Pt-CGO and Pd-CGO by dual infiltrations further lowered the electrode polarization resistance. The morphology of the catalyst showed well dispersed metal nanoparticles distributed in the matrix of CGO. The nanocrystalline alloys of $\mathrm{Ni}-\mathrm{Pt}$ were formed in $\mathrm{Ni}-\mathrm{Pt}-\mathrm{CGO}$ electrocatalyst along with the coexistence of $\mathrm{Ni}$ and $\mathrm{Pt}$ nanoparticles as separate phases.

\section{Acknowledgment}

The financial support from Department of Energy Conversion and Storage within the project SOFC 400 is gratefully acknowledged.

\section{Appendix A. Supporting information}

Supporting information associated with this article can be found, in the online version, at doi:10.1016/j.jpowsour.2012.05.036.

\section{References}

[1] J. Huijsmans, F. Van Berkel, G. Christie, J. Power Sources 71 (1998) 107-110.

[2] X. Zhang, M. Robertson, S. Yick, C. Deces-Petit, E. Styles, W. Qu, Y. Xie, R. Hui, J. Roller, O. Kesler, J. Power Sources 160 (2006) 1211-1216.

[3] P. Kim, D. Brett, N. Brandon, J. Power Sources 189 (2009) 1060-1065.

[4] D.G. Ivey, E. Brightman, N. Brandon, J. Power Sources 195 (2010) 6301-6311.

[5] U.P. Muecke, K. Akiba, A. Infortuna, T. Salkus, N.V. Stus, L.J. Gauckler, Solid State Ionics 178 (2008) 1762-1768.

[6] P. Lohsoontorn, D. Brett, N. Brandon, J. Power Sources 175 (2008) 60-67.

[7] P. Lohsoontorn, D. Brett, N. Brandon, J. Power Sources 183 (2008) 232-239.

[8] P.R. Slater, D.P. Fagg, J.T.S. Irvine, J. Mater. Chem. 7 (1997) 2495-2498.

[9] M. Gong, X. Liu, J. Trembly, C. Johnson, J. Power Sources 168 (2007) 289-298.

[10] P. Blennow, K.K. Hansen, L. Wallenberg, M. Mogensen, J. Eur. Ceramic Soc. 27 (2007) 3609-3612.

[11] D.J. Cumming, J.A. Kilner, S. Skinner, J. Mater.Chem. 13 (2011) 5021-5026.

[12] S.P. Jiang, Int. J. Hydrogen Energy 37 (2011) 449-470.

[13] T. Sholklapper, C. Jacobson, S. Visco, L. De Jonghe, Fuel Cells 8 (2008) 303-312.

[14] A.M. Hussain, J.V.T. Høgh, T. Jacobsen, N. Bonanos, Int. J. Hydrogen Energy 37 (2012) 4309

[15] H. Borchert, Y. Borchert, V.V. Kaichev, I.P. Prosvirin, G.M. Alikina, A.I. Lukashevich, V.I. Zaikovskii, E.M. Moroz, E.A. Paukshtis, V.I. Bukhtiyarov, J. Phys. Chem. B 109 (2005) 20077-20086.

[16] Y. Nabae, I. Yamanaka, M. Hatano, K. Otsuka, J. Electrochem. Soc. 153 (2006) A140.

[17] J.S. Kim, V.V. Nair, J.M. Vohs, R.J. Gorte, Scr. Mater. (2010).

[18] M. Guillodo, P. Vernoux, J. Fouletier, Solid State Ionics 127 (2000) 99-107.

[19] A. Tanksale, C. Zhou, J. Beltramini, G. Lu, J. Inclusion Phenomena Macrocyclic Chem. 65 (2009) 83-88.

[20] P. Blennow, A. Hagen, K.K. Hansen, L. Wallenberg, M. Mogensen, Solid State Ionics 179 (2008) 2047-2058.

[21] J. Rossmeisl, W.G. Bessler, Solid State Ionics 178 (2008) 1694-1700.

[22] T. Hibino, A. Hashimoto, M. Yano, M. Suzuki, M. Sano, Electrochim. Acta 48 (2003) 2531-2537.

[23] A. Babaei, S.P. Jiang, J. Li, J. Electrochem. Soc. 156 (2009) B1022-B1029.

[24] M. Laguna-Bercero, S. Skinner, J. Kilner, J. Power Sources 192 (2009) 126-131. 